\title{
Effects of Pilates Exercises on the Social Physical Concern of Patients with Fibromyalgia Syndrome: A Pilot Study
}

\author{
Fibromiyalji Sendromlu Hastalarda Pilates Egzersizlerinin \\ Sosyal Fiziksel Kaygı Düzeyine Etkileri
}

Nimet Korkmaz

Uludağ Üniversitesi Eğitim Fakültesi, Beden Eğitimi ve Spor Bölümü, Bursa, Turkey

\section{Abstract}

Objective: The goal of this study was to investigate the effect of Pilates exercises on the social physical concern (SPC) of patients with fibromyalgia syndrome (FMS). We also aimed to determine the effect of Pilates exercises on strength, body mass index (BMI), pain, and depression.

Materials and Methods: Twenty-five female patients with an age range of 33 to 63 years (mean: $49.16 \pm 7.51$ ) were evaluated. All patients had been diagnosed with FMS according to the American College of Rheumatology (ACR) criteria. Patients underwent a Pilates exercise program consisting of one hour of exercise performed three times per week for 12 weeks. Prior to exercise and at the end of the $12^{\text {th }}$ week, the patient's weight, grip strength of the hands, back strength, body fat ratio, and BMI were measured. Before- and after-exercise measurements were compared. The patient pain level was determined using the visual analog scale (VAS). Beck Depression Inventory (BDI) was used to define the depression level of patients. SPC level of patients was obtained by Social Physique Anxiety Scale (SPAS). The correlations between SPC scores and anthropometric values and pain and depression levels were evaluated.

Results: Pilates exercises significantly improved the weight, BMI, body fat ratio and SPC and pain level of the patients. No statistically significant change was found for grip strength of either hand or back strength. A statistically significant correlation was found between SPC scores and the body fat ratio, weight, $\mathrm{BMI}$, and pain and depression scores of patients before and after the exercise program.

Conclusion: A 12-week Pilates program had positive effects on anthropometric parameters, SPC, and pain and depression levels of FMS patients. Patients with FMS can safely perform Pilates exercises to control weight, improve physical appearance, and reduce SPC and pain and depression levels, and no adverse side effects were observed. To obtain further evidence regarding the effectiveness of Pilates exercises, additional studies involving different patient groups are required.(Turk J Rheumatol 2010; 25: 201-7)

Key words: Fibromyalgia, social physical concern, pilates exercises

Accepted: 22.10 .2010

\section{Özet}

Amaç: Fibromiyalji sendromu (FMS) olan hastalarda Pilates egzersizlerinin sosyal fiziksel kaygı (SPC) seviyesine olan etkisini araștırmak. Aynı zamanda Pilates egzersizlerinin mukavemet, vücut kütle indeksi (BMI), ağrı ve depresyon düzeylerine olan katkısını belirlemek.

Yöntem ve Gereçler: Yașları 33 ile 63 arasında olan 25 hasta çalısmaya dahil edildi. Tüm hastaların FMS tanısı Amerikan Romatizma Koleji (ACR) kriterlerine göre konmuștur. 1 saatlik bir Pilates egzersiz programı hastalara haftada 3 kez olmak üzere 12 hafta boyunca uygulandı. Egzersiz öncesi ve 12. haftanın sonunda, hastaların ağırlıkları, ellerin kavrama kuvveti, bel kuvveti, vücut yağ oranları ve BMI ölçüldü. Hastaların ağrı düzeyleri görsel analog skala (VAS) kullanılarak belirlendi. Depresyon seviyeleri Beck Depression anketi (BDI) ile belirlendi. SPC düzeyleri sosyal fiziksel anksiyete anketi (SPAS) uygulanarak ölçüldü. Katılımcıların SPC değerleri ile anropometrik ölçümleri, ağrı, depresyon düzeyleri arasında korelasyon araștırıldı.

Bulgular: Pilates egzersizleri hastaların ağırlığı, BMI, yağ oranı ve SPC değerlerini iyileștirmiștir. El kavrama gücü ve sırt gücü için istatistiksel olarak anlamlı bir etkisi bulunamadı. Egzersiz programı öncesi ve sonrası, ölçülmüș vücut yağ oranı, ağılık, BMI ve SPC düzeyi arasında önemli bir korelasyon bulundu.

Sonuç: Oniki haftalık Pilates programının FMS hastalarındada antropometrik ölçüler, SPC, ağrı ve depresyon üzerinde olumlu etkileri vardı. FMS hastalar kilo kontrolü, fiziksel görünümünü iyileștirmek ve SPC seviyelerini azaltmak için Pilates egzersizlerini hiçbir yan etkisi olmadan güvenli bir șekilde uygulayabilirler. Pilates egzersizlerinin etkinliği hakkında daha fazla kanıt elde etmek için, farklı hasta gruplarını içeren ek çalıșmalar gerekmektedir. (Turk J Rheumatol 2010; 25: 201-7)

Anahtar sözcükler: Fibromiyalji, sosyal fiziksel kaygı, pilates egzersizleri

Alındığı Tarih: 21.03.2010 Kabul Tarihi: 22.10.2010

Received: 21.03 .2010

Address for Correspondence: Dr. Nimet Korkmaz, Uludağ Üniversitesi Eğitim Fakültesi, Beden Eğitimi ve Spor Bölümü, Bursa, Turkey Phone: +902242940693 E-mail: nhasil@uludag.edu.tr 


\section{Introduction}

Fibromyalgia syndrome (FMS) is a common rheumatological condition characterized by chronic widespread pain and a reduced pain threshold as well as hyperalgesia and allodynia. Associated features include fatigue, depression, anxiety, sleep disturbance, headache, migraine, variable bowel habits, diffuse abdominal pain and altered urination frequency (1). Although the precise pathogenesis of FMS remains unknown, peripheral and central hyper-excitability of the spine or brainstem and altered pain perception and somatization have been hypothesized and demonstrated in some patients (2). Treatment of FMS is usually symptomatic due to the lack of understanding of its etiology and pathophysiology. Several treatment modalities, ranging from antidepressant therapy to biofeedback and electro-acupuncture, have been suggested since the definition of the illness $(1,3)$. Exercise programs have been reported to be helpful in FMS patients in several studies. Programs including stretching, strength maintenance and aerobic conditioning have been accepted as part of standard treatment protocols (4-9). However, standardization of the type, intensity and duration of exercise has not yet been well established $(10,11)$.

Pilates is an exercise approach that was founded by the teachings of Joseph Pilates (1880-1967) and was initially practiced almost exclusively by athletes and dancers. It has become a fast-growing and popular trend in rehabilitation and fitness in recent years (12). Pilates combines Eastern and Western practices, including yoga, dance, durability, strength training, and gymnastics. The basic goal of Pilates training is focused on improvement of general body flexibility and health, emphasizing "core" (truncal) strength, posture and coordination between breathing and movement (13). The Pilates method has been hypothesized to help maintain the natural flexibility of the spine and limbs while increasing core strength. Researchers studying the clinical effects of Pilates have agreed that additional research in the Pilates method is required. The Pilates method that was developed by Joseph Pilates has been updated in recent years and has started to be implemented in fitness centers and for rehabilitation purposes. This modern Pilates approach can be defined as comprehensive body-mind conditioning, the main goals of which are efficient movement, core stability and enhanced performance (14). In terms of rehabilitation, the return to functional activities is also a primary objective since the method encourages movement earlier in the treatment process by providing necessary assistance (15). There are recent scientific researches evaluating the effectiveness of the Pilates method on neuromuscular conditions (16-19). In addition to its adoption by training programs designated for healthy people as part of general fitness programs, Pilates has also been suggested as a therapeutic modality for several musculoskeletal disorders $(15,16)$. The recent studies also show the positive effects of Pilates exercises in FMS patients (20).

Social physical concern (SPC) is a concern experienced by people regarding the evaluation of their physical appearance by others (21). The concept of SPC is rooted in the self-presentation theory, which comprises the effort to control one's behaviors before other people and to modify one's appearance $(22,23)$. As SPC is related to the physical appearance of individuals, the body mass index (BMI) and body fat ratio of a patient play a significant role. In particular, individuals are more likely to participate in slimming programs due to current societal preferences for slimmer role models. In fact, they sometimes exercise solely for these reasons (24). It is expected that individuals who have better physical performance and who perform physical exercises would have lower SPC than those who do not practice physical exercises. Findings in the contemporary literature support this theory (25-27). Engaging in activities that require physical effort and exercise improve a person's physical appearance and are beneficial for general health. According to Lantz et al. (28), a number of studies demonstrate that some people perform exercises to reduce their SPC, while others prefer not to participate in physical activities due to their high SPC. Physical distress related to FMS may lead to the development of anxiety and depression (29). FMS has a substantial negative impact on social and occupational functions. Patients report disrupted relationships with family and friends, social isolation, reduced daily activity and leisure activities, and avoidance of physical activity (30). In these patients, SPC and the factors that lead to this concern, including BMI, body fat ratio and lack of static strength, may be expected to contribute to the increase in anxiety. Physical exercise may positively affect these factors.

The aim of this study was to examine the effectiveness of Pilates exercises on the SPC of patients with FMS and to determine the relationships between the SPC and BMI, body fat ratio, strength, and pain and depression levels.

\section{Materials and Methods}

Patients: Twenty-five female patients with an age range of 33 to 63 years (mean: $49.16 \pm 7.51$ ), who were admitted to Rheumatology Clinics with the diagnosis of FMS according to the American College of Rheumatology (ACR) criteria (14), were included in this study. None of the patients had an accompanying rheumatic disease, unstable hypertension, severe cardiopulmonary problem, or psychiatric disorder affecting patient compliance. None of them had engaged in an exercise program and they were all sedentary. The patients were fully informed about the nature and purpose of the study and an informed consent was obtained from each of them. Approval by the local ethics committee was obtained for the study. 
Treatment protocol: All patients participated in an education session led by a physiatrist that provided a description of diagnosis and treatment methods in FMS. A one-hour Pilates exercise program was given by a certified trainer to patients three times per week for 12 weeks. The exercise program followed the basic principles of the Pilates method. Our protocol comprised the following components of Pilates-based exercises: strength and stabilization, flexibility and range of motion, proper body alignment, balance, coordination, and body awareness. Resistance bands and $26 \mathrm{~cm}$ Pilates balls were used as supportive equipment. The exercise sections consisted of 5 minutes breathing, 10 minutes warm-up, 35 minutes conditioning phase and 10 minutes cool-down.

Breathing Section: The goal is to coordinate breath with movement and to connect mind, body and breath. Three sets of exercises are used: breathing in seated position, breathing in supine position and breathing in supine double V position. General recommendation for breathing is: air enters in through the nose or mouth, down the throat and into the lungs, which inflate and fill up the ribcage. The exhalation is forced, which helps to create an abdominal brace, fully engaging all the abdominal muscles by bilaterally contracting the obliques.

Warm-up Section: This section consists of imprint position, bridge, articulated cat, and partial roll down exercises. The general purpose is to increase body core temperature and to warm and prepare muscles and joints for movements that follow.

Conditioning Section: This period includes a series of exercises like knee sway, rolling like a ball, modified hundred, leg circles, single leg stretch, spine stretch forward, flight, spine twist, and side leg lift. The exercises are performed in a slow and controlled manner and flow smoothly from one to another.

Cool-down: This section includes exercises like modified child's pose, cat and supine relaxation. The purpose of the end of the class cool-down is to relax, increase flexibility and promote mind-body awareness. In each 1 hour session, the above exercises are repeated 8 times during the first 4 weeks then 12 times for the remaining 8 weeks.

Evaluation parameters: Evaluations were made before (Week 0) and after (Week 12) the exercise program.

Pain: Pain evaluations were conducted in accordance with the visual analog scale (VAS) (31). The patients were asked to pinpoint their pain severity on a $10 \mathrm{~cm}$ long scale, and the distance from point 0 was measured.

Beck Depression Inventory (BDI): This questionnaire was used to evaluate the level of depression in the patients because of its previously reported validity and ease of application (32).

Social physical concern: SPC was assessed via a 12-item Social Physique Anxiety Scale (SPAS). The items within the scale developed by Hart, Leary and Rejeski (33) are answered using a 5-point Likert-type scale. The minimum score is 12 and the maximum is 60 . Higher SPAS scores are indicative of greater concern regarding physical appearance. The inventory consists of questions relevant to an individual's discomfort, derived from observation of their physical appearance by others and perception of their own physical appearance. The validity of the SPAS was previously confirmed on a Turkish student by Asscı (34).

Anthropometric measures: The weight, height and $\mathrm{BMI}$ of each patient were measured by a Sport Expert brand Anthropometry Set (MED-AN 100). The fat percentage of each patient was measured by an Omron brand (BF 306, Japan) body fat scale.

Strength parameter measurements: Hand grip and back strength values were measured by a manual dynamometer (MED DYN 100 Sport Expert). Left-right handgrip strength and back strength tests were given twice to each patient. The higher score was recorded.

\section{Statistical analysis}

Data were assessed using the SPSS program (version 16.0 for Windows). The normality assumption was tested with the Shapiro-Wilks test. To compare VAS score, BDI score, weight, BMI, body fat ratio, left handgrip strength, right handgrip strength, back strength, and SPAS scores before and after Pilates exercises, paired sample t test or Wilcoxon sign test was used according to the distribution of the data. Correlations were evaluated using Spearman's correlation coefficient. $P$ value $<0.05$ was considered as statistically significant. Data are reported as mean \pm standard deviation and median (min, max).

\section{Results}

The pain level, BDI score, weight, BMI, grip strength of both hands, back strength, and SPC level of the patients before and after the exercise program are shown in Table 1. The data indicate that Pilates exercises had positive effects on pain, depression, weight, BMI, body fat ratio, and the SPC level of patients with FMS. The changes in SPC score, pain, depression, and anthropometric measures at the end of exercises were statistically significant $(p<0.05)$ No statistically significant differences were observed in grip strength of both hands or back strength before and after exercises.

The relationship between anthropometric measurements, pain, depression, and SPC scores obtained before and after the Pilates exercises are shown in Table 2. Before exercise, a statistically significant correlation was found between SPC scores and pain, depression, weight, BMI, and body fat ratio $(p<0.001, p<0.001$, $p<0.05, p<0.001$, and $p<0.001$, respectively). After exercise, a statistically significant correlation was detected between SPC scores at week 12 and pain, depression, weight, BMI, and body fat ratio $(p<0.001, p<0.001$, $p<0.05, p<0.024$, and $p<0.023$, respectively). A significant relationship was not observed with age or height before and after the 12-week program. 


\begin{tabular}{|c|c|c|c|}
\hline Variables & $\begin{array}{c}\text { Pre-exercises }(\mathrm{N}=25) \\
\text { Mean } \pm \mathrm{SD} \\
\text { Median (min, max) }\end{array}$ & $\begin{array}{c}\text { Post-exercises }(\mathrm{N}=25) \\
\text { Mean } \pm \mathrm{SD} \\
\text { Median (min, max) }\end{array}$ & $p$ \\
\hline SPC Score (SPAS) & $\begin{array}{l}30.68 \pm 7.70 \\
30(16,46)\end{array}$ & $\begin{array}{l}26.32 \pm 6.91 \\
27(12,41)\end{array}$ & $\mathrm{p}<0.001$ * \\
\hline Pain (VAS) & $\begin{array}{l}6.19 \pm 1.79 \\
6(3.5,10)\end{array}$ & $\begin{array}{l}4.18 \pm 1.77 \\
4(1.8,7.8)\end{array}$ & $\mathrm{p}<0.001$ * \\
\hline Depresion (BDI) & $\begin{array}{c}12.44 \pm 7.73 \\
12(0,34)\end{array}$ & $\begin{array}{c}7.28 \pm 5.17 \\
7(1,21)\end{array}$ & $p<0.001 *$ \\
\hline Weight (kg) & $\begin{array}{c}75.42 \pm 11.81 \\
73(55.6,109)\end{array}$ & $\begin{array}{l}73.6 \pm 11.24 \\
71(56,107)\end{array}$ & $\mathrm{p}<0.001$ ** \\
\hline Fat $\%$ & $\begin{array}{c}40.56 \pm 5.09 \\
40.5(30.7,48.5)\end{array}$ & $\begin{array}{c}38.74 \pm 5.54 \\
37(28.4,49.6)\end{array}$ & $\mathrm{p}<0.001$ ** \\
\hline BMI $\left(\mathrm{kg} / \mathrm{m}^{2}\right)$ & $\begin{array}{c}30.02 \pm 4.58 \\
28.8(21.6,39.1)\end{array}$ & $\begin{array}{c}29.30 \pm 4.50 \\
28.2(22.2,39.8)\end{array}$ & $\mathrm{p}<0.001 * *$ \\
\hline $\begin{array}{l}\text { Left Handgrip } \\
\text { Strength }(\mathrm{kg})\end{array}$ & $\begin{array}{c}13.61 \pm 3.21 \\
14.09(5.05,19.95)\end{array}$ & $\begin{array}{c}13.90 \pm 3.15 \\
13.63(7.7,20.5)\end{array}$ & $\mathrm{p}<0.601$ ** \\
\hline $\begin{array}{l}\text { Right Handgrip } \\
\text { Strength }(\mathrm{kg})\end{array}$ & $\begin{array}{c}14.84 \pm 4.38 \\
14.9(6.56,26.81)\end{array}$ & $\begin{array}{c}13.74 \pm 3.12 \\
13.75(6.78,21.12)\end{array}$ & $\mathrm{p}<0.614^{* *}$ \\
\hline $\begin{array}{l}\text { Back } \\
\text { Strength (kg) }\end{array}$ & $\begin{array}{c}39.62 \pm 14.28 \\
36(20.3,74.9)\end{array}$ & $\begin{array}{c}38.16 \pm 13.86 \\
38.6(14.8,70.4)\end{array}$ & $\mathrm{p}<0.576$ ** \\
\hline
\end{tabular}

BDI: Beck depression inventory, BMI: Body mass index, N: Number of patients, SD: Standard deviation, SPAS: Social physique anxiety scale VAS: Visual analog scale, * Wilcoxon test, ** paired samples $t$ tests

Table 2. Correlations of social physical concern scores with anthropometric parameters, pain and depression measurements obtained before and after Pilates exercises

\begin{tabular}{lccccccc}
\hline & Age & Height & Weight & BMI & Fat $\%$ & Pain & Depression \\
\hline Pre-exercises & $\mathrm{p}=0.146$ & $\mathrm{p}=0.270$ & $\mathrm{p}=0.05$ & $\mathrm{p}=0.001$ & $\mathrm{p}=0.001$ & $\mathrm{p}=0.001$ & $\mathrm{p}=0.001$ \\
SPC Score & $\mathrm{r}=0.299$ & $\mathrm{r}=-0.229$ & $\mathrm{r}=0.541$ & $\mathrm{r}=0.640$ & $\mathrm{r}=0.510$ & $\mathrm{r}=0.410$ & $\mathrm{r}=0.310$ \\
Post-exercises & $\mathrm{p}=0.455$ & $\mathrm{p}=0.326$ & $\mathrm{p}=0.05$ & $\mathrm{p}=0.024$ & $\mathrm{p}=0.023$ & $\mathrm{p}=0.001$ & $\mathrm{p}=0.001$ \\
SPC Score & $\mathrm{r}=0.157$ & $\mathrm{r}=-0.205$ & $\mathrm{r}=0.387$ & $\mathrm{r}=0.451$ & $\mathrm{r}=0.392$ & $\mathrm{r}=0.392$ & $\mathrm{r}=0.292$ \\
\hline
\end{tabular}

BMI: Body mass index, Fat\%: Body fat ratio, p: Spearman's correlation significance level, $r$ : Spearman's correlation coefficient, SPC: Social Physical Concern

\section{Discussion}

The results of the present study indicate that a 12-week Pilates program had positive effects on the SPC of patients with FMS. Their pain scores and BDI scores were improved at the end of the 12-week Pilates program. Back strength and hand grip strength had not changed significantly at the end of the exercise program. Anthropometric measurements including weight, BMI and body fat ratio had improved at the end of the 12-week Pilates exercise program.

Although the Pilates method has been employed as part of fitness programs in the studios for a long time, it has only recently been shown to improve flexibility, abdominal muscular endurance, and static and dynamic balance in healthy people, and subsequently has become the subject of scientific research investigating its efficiency in patients with musculoskeletal diseases (35-40). Chronic low back pain patients were reported to benefit from
Pilates exercises (41). The basic goal of Pilates training is improvement in body flexibility and general health, with emphasis on strength, posture and coordination of breathing with movement. Another important contribution of the Pilates technique is avoidance of positions that demand unnecessary muscle recruitment and the ensuing early fatigue, decreased stability and impaired recovery (42). Since most FMS patients feel tired and unrefreshed as a result of interruption of deep sleep by bursts of brain activity similar to wakefulness due to electroencephalographically documented $\alpha-\delta$ wave intrusions, these patients may have difficulty complying with the standard aerobic exercises (43). Pilates may increase the compliance of such patients by avoiding the above-mentioned exercise fatigue as was corroborated by the results of our study, in which all patients could finish the training program without any physical problems. While conventional exercise programs have a tendency for weakening the already weak muscles and 
strengthening the already strong muscles and may lead to an unbalanced muscular build and resultant complications of chronic low back pain and several types of injuries, Pilates techniques aim to correct body posture by training the muscular system as a whole. More specifically, the Pilates concept locates the body center in deep muscles in proximity to the spine and the training aims to form a robust musculoskeletal structure in the upper body by providing a balanced back and abdominal musculature (42). FMS patients have muscular asymmetry and antalgic postural problems (44). Jones et al. (45) showed that FMS may affect peripheral and/or central mechanisms of postural control leading to significantly impaired balance. Johnson et al. (35) reported improvement in dynamic balance following 10 Pilatesbased exercise sessions when compared to the control group. Pilates exercises may have contributed to the positive results in our study as well by improving impaired posture and balance.

The effect of exercise on FMS is continuing to be investigated by researchers. In a recent study reported by Altan et al. (20), a 12-week Pilates training among individuals with FMS had improved the parameters of pain, fatigue, morning stiffness, and tender points when compared to a control group. The improvements were evaluated by patient and physician's global assessments, fibromyalgia impact questionnaire, 6-minute walking test, chair test, Nottingham Health Profile, and BDI. Martin et al. (5) observed improvement in the parameters of aerobic fitness, tender points and total myalgic score in subjects that completed a 6-week exercise program compared to those that completed a relaxation program, and suggested that even better results could be obtained with longer exercise periods. Aerobic endurance exercises spanning 12 weeks were found to have a positive effect on the fitness and well-being of FMS patients (6). Ramsay et al. (46), in contrast, failed to show any superiority of supervised aerobic exercise for 12 weeks over a home exercise program for any parameter except for psychological well-being. A recent review has suggested that supervised aerobic exercise training and strength training may have a beneficial effect on physical capacity and clinical symptoms in FMS patients (47). Unfortunately, development of a standard exercise protocol in FMS has not yet been possible due to variability in the type of exercise, duration, follow-up period, and selection of evaluation parameters among the above-mentioned studies.

Pilates exercises involved in this study showed no positive effect on the grip strength of both hands or back strength. These findings indicate that the Pilates exercises used in the present study were not effective in developing static strength. This limitation may be due to the lack of inclusion of Pilates exercises with movement that can increase handgrip strength. Importantly, it was expected that participants would show an increase in back strength.
Pilates training that focuses on back extensors and abdominal musculature, on the transversus abdominus in particular, is referred to as core strengthening. The fact that no significant improvement in back strength was found may be because the group consisted of FMS patients rather than healthy individuals. As a result, study participants may have been unable to perform the exercises adequately due to physical pain. The lack of the anticipated improvement in back strength may be deemed normal when applying this type of exercise program to FMS patients.

The results of the present study indicate that Pilates exercises improve the level of pain. Pilates involves closed kinetic-chain exercises, which may provide the compressive and decompressive forces necessary to foster nutrition to joints and cartilage to reduce degenerative risk. Pilates may have a role in attenuating the predisposition to chronic axial musculoskeletal pain caused by spinal instability. A study conducted by Valencia et al. (48) evaluated pain perception, muscular flexibility, and illness impact in women with fibromyalgia. Twenty FMS patients were randomly assigned to one of two training groups, one following a program of kinesiotherapy and active muscular stretching and one using techniques of Global Myofascial Physiotherapy. Both groups met twice a week for 12 weeks, for a total of 150 minutes each week. Flexibility and illness impact were measured. No significant differences were observed between the two treatment groups in the initial values or in the results at the end of the program or after the follow-up, so neither program proved to be superior.

The depression level of the patients in this study improved significantly after the exercise program. The presence of depressive symptoms is associated with a great impairment in patients with FMS: indeed, the psychiatric comorbidity lowers the pain threshold and worsens the quality of life of FMS patients (49). There is well-established evidence that aerobic exercises improve quality of life by reducing pain, the number of sensitive points and depression (4). There are also some studies related to depression measurements in patients with FMS that yielded conflicting results. In a study carried out by Ramsey et al. (46), one group was assigned to perform aerobic exercises and the other group was assigned to perform home exercises for a period of 48 weeks. No amelioration was found in levels of depression, as measured by the BDI scores, either within or between groups.

A broad, web-based review of the literature (PubMed, SPORT Discuss and ProQuest 5000 International) indicated that previous research investigating the relationship between $\mathrm{BMI}$, body fat ratio and SPC was conducted in healthy individuals; however, research investigating the relationship between SPC and parameters such as BMI and body fat ratio, as well as basic physical conditions such as strength, had not been 
carried out in patients with FMS. In examining the relationship between the measured parameters before and after exercise, a statistically significant correlation was found between SPC scores and weight, BMI and body fat ratio. A precise examination of the results shows that the pain and depression levels are improved more sensibly than the other measured variables. It should be noted that a decrease in weight and fat ratio are the main outcomes of the exercise program. Improvement in these parameters is associated with an improvement in the BMI. The effects of these physical appearance parameters on SPC are also positive. The relationship between SPC and body composition in patients with fibromyalgia has not been previously established. Although there is no control group with which to compare the outcome of this research, the findings and results of the present study may contribute to clarification of the relationship between SPC and exercise in patients with FMS.

In conclusion, the present study shows that Pilates exercise significantly improves pain depression and the SPC level in fibromyalgia patients. An improvement in anthropometric parameters is also observed. The exercise program does not show any effects on the strength parameters of patients. Further studies should be considered, including endurance exercise, to evaluate pain, depression and strength in FMS patients to improve the SPC. According to the results of this study, Pilates exercise can be recommended as an effective supplement to the treatment of FMS patients. We believe that further research, including a larger patient population and a longer follow-up period, could better assess the benefit of this popular physical exercise method.

\section{Acknowledgements}

The author would like to express his gratitude to Dr. Lale İnceoglu Altan, whose expertise, understanding and patience added considerably to the realization of this work. I appreciate her vast knowledge and skill in the area of fibromyalgia.

\section{Conflict of Interest}

No conflict of interest declared by the authors.

\section{References}

1. Carville SF, Arendt NS, Bliddal H, Blotman F, Branco JC, Buskila $D$, et al. Evidence-based recommendations for the management of fibromyalgia syndrome. Ann Rheum Dis 2008; 67: 536-41.

2. Henriksson KG. Fibromyalgia from syndrome to disease. Overview of pathogenetic mechanisms. J Rehab Med 2003; 41(Suppl): 89-94.

3. Wolfe $F$. The fibromyalgia syndrome: A consensus report on fibromyalgia and disability. J. Rheumatol 1996; 23: 534-9.

4. Meiworm L, Jakop E, Walker UA, Peter HH, Keul J. Patients with fibromyalgia benefit from aerobic endurance exercise. Clin Rheumatol 2000; 19: 253-7.
5. Martin L, Nutting A, Macintosh BR, Edworthy SM, Butterwick $D$, Cook J. An exercise program in the treatment of fibromyalgia. J Rheumatol 1996; 23: 1050-3.

6. Clark SR, Jones KD, Burckhardt CS, Bennet R. Exercise for patient with fibromyalgia: risks versus benefits. Curr Rheumatol Rep 2001; 3: 135-46.

7. Gowans SE, deHueck A, Voss S, Richardson M. A randomized, controlled trial of exercise and education for individuals with fibromyalgia. Arthritis Care Res 1999; 12: 120-8.

8. McCain G, Bell DA, Mai FM. A controlled study of the effects of a supervised cardiovascular fitness training program on the manifestations of primary fibromyalgia. Arthritis Rheum 1988; 31: 1135-41.

9. Altan L, Bingöl U, Aykaç M, Koc Z, Yurtkuran M. Investigation of the effects of pool-based exercise on fibromyalgia syndrome. Rheumatol Int 2004; 24: 272-7

10. Busch AJ, Schachter CL, Overend TJ, Peloso PM, Barber KA. Exercise for fibromyalgia: a systematic review. J Rheumatol 2008; 35: 1130-44.

11. Busch AJ, Barber KA, Overend TJ, Peloso PM, Schachter CL. Exercise for treating fibromyalgia syndrome. Cochrane Database Syst Rev 2007; 17: CD003786.

12. Friedman P, and Eisen G.(eds) The pilates method of Physical and mental conditioning. Penguin Books Ltd. 10.th edition. London, England 2005.

13. Latey P. Updating the principles of the pilates method. J Bodyw Mov Ther 2002; 6: 94-101.

14. Herrington $L$, Davies R. The influence of pilates training on the ability to contract the Transversus Abdominis muscle in asymptomatic individuals. J Bodyw Mov Ther 2005; 9: 52-7.

15. Levine B, Kaplanek B, Scafura D, Jaffe WL. Rehabilitation after total hip and knee arthroplasty: a new regimen using Pilates training. Bull NYU Hosp Jt Dis 2007; 65: 120-5.

16. Blum CL. Chiropractic and pilates therapy for the treatment of adult scoliosis. J Manipulative Physiol Ther 2002; 25: E3.

17. Kloubec JA. Pilates for improvement of muscle endurance, flexibility, balance, and posture. J Strength Cond Res 2010; May 24: 661-7.

18. Culliagan P, Scherer J, Dyer K, Priestley JL, Guingon-White G, Delvecchio $D$, et al. A randomized clinical trial comparing pelvic floor muscle training to a Pilates exercise program for improving pelvic muscle strength. Int Urogynecol J Pel 2010; 21: 401-8.

19. Rogers K, Gibson AL. Eight-Week Traditional Mat Pilates Training-Program Effects on Adult Fitness Characteristics. Res Q Exercise Sport 2009; 80: 569-74.

20. Altan L, Korkmaz N, Bingöl U, Günay B. Effect of Pilates Training on People With Fibromyalgia Syndrome: A Pilot Study, Arch Phys Med Rehab 2009; 90: 1983-8.

21. Martin JJ, Kliber A, Kulinna PH, Fahlman M. Social physique anxiety and muscularity and appearance cognitions in college men. Sex Roles 2006; 55: 151-8.

22. Eklund RC, Crawford S. Active women, social physique anxiety, and exercise. J Sport Exercise Psy 1994; 16: 431-48.

23. Huddy DC, Niemann DC, Johnson RL. Relationship between body image and percent body fat among college male varsity athletes and non-athletes. Percept Motor Skill 1993; 77: 851-7.

24. Hausenblas HA, Fallon EA. Relationship among body image, exercise behavior, and exercise dependence symptoms. Int J Eat Disorder 2002; 32: 179-85. 
25. Frederick CM, Morrison CS. Social physique anxiety: Personality constructs, motivations, exercise attitudes and behaviors. Percept Motor Skill 1996; 82: 963-72.

26. Finkenberg ME, DiNucci JM, McCune SL, Chenette T, McCoy P. Commitment to physical activity and anxiety about physique among collage women. Percept Motor Skill 1998; 87: 1393-4.

27. Kowalski NP, Crocker PR, Kowalski KC. Physical self and physical activity relationships in college women: Does social physique anxiety moderate effects. Res Q Exercise Sport 2001; 72: 55-62.

28. Lantz CD, Hardy $C J$, Ainsworth BE. Social physique anxiety and perceived exercise behavior. Journal of Sport Behavior 1997; 20; 83-93.

29. Merskey $\mathrm{H}$. Social influences on the concept of fibromyalgia. CNS Spectr; 2008 Mar; 13 (Suppl 5): 18-21.

30. Arnold LM, Crofford LJ, Mease PJ, Burgess SM, Palmer SC, Abetz $\mathrm{L}$, et al. Patient perspectives on the impact of fibromyalgia. Patient Educ Couns 2008; 73: 114-20.

31. Wewers ME, Lowe NK. (1990) A critical review of visual analogue scales in the measurement of clinical phenomena. Research in Nursing and Health 1990; 13: 227-36.

32. Goldenberg DL. Psyciatric and psychologic aspects of fibromyalgia syndrome. Rheum Dis North America 1989; 15: 105-14.

33. Hart EA, Leary MR, Rejeski WJ. The measurement of social Physique Anxiety 1989; 11: 94-104.

34. Așcı H.F., Mülazımoğlu-Ballı, Ö. "Reliability and Validity of Social Physique Anxiety Scale". Spor Bilimleri Dergisi Hacettepe J of Sport Sciences 2006; 17: 11-9.

35. Johnson EG, Larsen A, Wilson CA, MPT, Kennedy KL. The effects of Pilates-based exercise balance in healthy adults. J Bodyw Mov 2007; 11: 238-42.

36. Segal NA, Hein J, Basford JR. The effects of Pilates training on flexibility and body composition: an observational study. Arch Phys Med Rehabil 2004; 85: 1977-81.

37. Sekendiz B, Altun O, Korkusuz F, Akın S. Effects of Pilates exercise on trunk strength, endurance and flexibility in sedentary adult females. 2007; 11: 318-26.
38. Jago $R$, Jonker ML, Missaghian M, Baranowski T. Effect of 4 weeks of Pilates on the bodycomposition of young girls. Prev Med 2006; 42: 177-80.

39. Curnow D, Cobbin D, Wyndham J, Boris Choy ST. Altered motor control, posture and the Pilates method of exercise prescription. J Bodyw Mov Ther 2009; 13: 104-11.

40. Bernardo LM. The effectiveness of Pilates training in healthy adults: An appraisal of the research literature. J Bodyw Mov Ther 2007; 11: 106-10.

41. La Touche R, Escalante K, Linares MT. Treating non-specific chronic low back pain through the Pilates Method. J Bodyw Mov Ther 2008; 12: 364-70.

42. Muscolino JE, Cipriani S. Pilates and the 'Powerhouse' I. J Bodyw Mov Ther 2004; 8: 15-24.

43. Hamilton NA, Affleck G, Tennen $H$, Karlson $C$, Luxton $D$, Preacher KJ, et al. Fibromyalgia: the role of sleep in affect and in negative event reactivity and recovery. Health Psychol 2008; 27: 490-7.

44. Mitani $Y$, Fukunaga M, Kanbara K, Takebayashi N, Ishino S, Nakai Y. Evaluation of psychophysiological asymmetry in patients with fibromyalgia syndrome. Appl Psychophysiol Biofeedback 2006; 31: 217-25.

45. Jones KD, Horak FB, Winters-Stone K, Irvine JM, Bennett RM. Fibromyalgia is associated with impaired balance and falls. J Clin Rheumatol 2009; 15: 16-21.

46. Ramsay C, Moreland J, Ho M, Joyce S, Walker S, Pullar T. An observer-blinded comparison of supervised and unsupervised aerobic exercise regimens in fibromyalgia. 2000; 39: 501-5.

47. Busch AJ, Schachter CL, Overend TJ, Peloso PM, Barber KA. Exercise for fibromyalgia: a systematic review. J Rheumatol 2008; 35: 1130-44.

48. Valencia M, Alonso B, Alvarez MJ, Barrientos MJ, Ayán C, Martín Sánchez V. Effects of 2 physiotherapy programs on pain perception, muscular flexibility, and illness impact in women with fibromyalgia: a pilot study J Manipulative Physiol Ther 2009; 32: 84-92.

49. Aguglia A, Salvi V, Maina G, Rossetto I, Aguglia E. Fibromyalgia syndrome and depressive symptoms: Comorbidity and clinical correlates, J Affect Disord 2010 Jul 30. 